\title{
Measurement of the synthesis of liver-produced plasma proteins with special reference to their regulation by dietary protein and amino acid supply
}

\section{By R. Hoffenberg*, Division of Metabolism, Medical Research Council Clinical Research Centre, Watford Road, Harrow, Middlesex}

About $300 \mathrm{~g}$ of protein are synthesized by the body each day. The plasma proteins account only for about $30 \mathrm{~g}$, of which albumin represents about $\mathrm{I} 2 \mathrm{~g}$. Yet, a great part of our knowledge of adaptation to protein or amino acid deprivation is based on studies of albumin metabolism and relatively few studies relate to the minor plasma proteins or specific tissue proteins. This is not surprising when one contrasts the comparative ease of studies on albumin metabolism with the technical problems of isolation and measurement of metabolic changes in other proteins. Clearly, adaptive changes in albumin metabolism cannot be regarded as representative of all tissue proteins, nor even of all plasma proteins. But the effect on albumin synthesis of alterations in amino acid supply is of interest, not only because of the importance of this protein in maintaining plasma oncotic pressure and in providing a transport mechanism for many substrates, but because the rate of its synthesis reflects one of the fundamental functions of the liver-albumin represents about a quarter of all the protein produced by this organ. Furthermore, the liver plays a vital role in regulating total body amino acid metabolism through its modulation of the postdigestive surge of amino acids into the portal blood-stream; adaptive changes in this buffering action of the liver - perhaps reflected in the rate of plasma protein synthesis - could materially alter the amount of amino acids available for metabolic purposes throughout the body.

\section{Methods of measuring synthesis rates of liver-produced plasma proteins}

Hepatic protein production has been studied by many different techniques, and it is desirable to examine these critically before considering the response to alterations in dietary protein or amino acid supply. For this purpose synthesis of albumin only will be considered, but most of the techniques may also be applied to the study of other liver-produced proteins.

\section{In vivo}

Indirect or inferential. Injection of albumin molecules labelled with radioactive iodine allows determination of a daily fractional catabolic rate for the protein; by relating this to the intravascular albumin pool an absolute figure can be derived for

* Present address: Department of Medicine, University of Birmingham. 
mass of protein catabolized per $\mathrm{d}$. Under steady-state conditions this figure can also be taken to represent synthesis. The validity of this derivation depends on several factors. (I) A high rate of catabolism may be found if the injected material has suffered even minor degrees of denaturation during fractionation, iodination, storage or sterilization, especially where this is achieved by heating (Freeman, 1970). (2) Calculation of a fractional catabolic rate from a plasma disappearance curve (Sterling, 195I) may be misleading in unsteady states where protein concentrations are changing; methods based on daily urinary radioactive iodide excretion expressed as a function of mean plasma total or specific radioactivity are more reliable in such circumstances (Campbell, Cuthbertson, Matthews \& McFarlane, 1956). (3) The equation of synthesis and catabolic rates depends absolutely on the existence of a steady state during the period of study, that is total protein in the whole system must remain constant and there must be no net exchange between intravascular and extravascular compartments; since these studies usually take IO-12 d to complete, such criteria are unlikely to obtain especially in the face of changing protein or amino acid supply.

Direct. Early work suggested that the rate of synthesis of a protein might be reflected by the gradual fall in its specific radioactivity after incorporation of a radioactive amino acid, and $\left[{ }^{35} \mathrm{~S}\right]$ methionine and $\left[{ }^{35} \mathrm{~S}\right]$ cystine were used for such studies. Problems arose because net plasma protein synthesis accounted for only a small part of the amino acid incorporation, and breakdown of more rapidly turning over proteins released amino acids which could be reutilized. It became apparent that information about the precursor amino acid specific radioactivity at the site of synthesis was necessary for precise interpretation of results-and this proved difficult to measure. The need for this information was circumvented by the introduction of the $\left[{ }^{14} \mathrm{C}\right]$ carbonate method based on simultaneous measurement of the specific radioactivity of two products of a single amino acid pool (McFarlane, $196_{3}$; Reeve, Pearson \& Martz, 1963); if the synthesis rate of one product could be measured, that of the other could be derived without access to the original amino acid pool. In this instance, the appearance of ${ }^{14} \mathrm{C}$ in urea and in the arginine residue of albumin were compared, and albumin synthesis rates were derived from the measured rate for urea. Since the method was first introduced, several studies have emphasized the need for: ( $I$ ) isolation of the protein under consideration in pure form; (2) careful measurement of urea synthesis, perhaps requiring simultaneous injection of $\left[{ }^{13} \mathrm{C}\right]$ urea; and $(3)$ correction for losses resulting from the processes of distribution and catabolism of labelled protein molecules released into the plasma during the period of study. This correction has usually been based on the disappearance of simultaneously-injected radioactive iodine-labelled albumin; this may itself be misleading because of selective removal of denatured molecules in the first few hours after injection.

Recently, a more serious criticism of the method has been expressed (Tavill, East, Black, Nadkarni \& Hoffenberg, I972). A careful study of the time-course of appearance of $\left[{ }^{14} \mathrm{C}\right]$ urea and $\left[{ }^{14} \mathrm{C}\right]$ albumin after a pulse-injection of ${ }^{14} \mathrm{CO}_{2}$ into the portal vein of an isolated perfused rat liver has suggested the possible existence 


\section{Vol. 31 Amino acid supply and polynucleotide and protein metabolism 267}

of separate precursor arginine pools for urea hydrolysis to carbon and for protein synthesis. If this is so, the method may be subject to new limitations under certain conditions. Nevertheless it has been possible to validate the $\left[{ }^{14} \mathrm{C}\right]$ carbonate method in many studies of differing character.

\section{In vitro}

In vitro systems using the perfused rat liver or incubation of liver slices lend themselves to greater flexibility and, at the same time, more rigid control without the complications that arise in in vivo studies, for example the influences of hormone secretion and fluxes between compartments. Apart from methods based on precursorproduct relationships, such in vitro systems can be exploited to make direct immunological determinations of homologous protein production, by perfusing or incubating with media containing either no protein or protein derived from heterologous sources (Hoffenberg, Gordon \& Black, r97r).

Recently, similar techniques have been applied to the study of isolated cells prepared from rat livers by perfusion with buffer containing hyaluronidase and clostridiopeptidase A [collagenase] (Berry \& Friend, 1969). After washing, cells may be incubated in artificial media, with or without amino acid supplements, and albumin production, measured serologically, can be shown to be linear over $3^{-4} \mathrm{~h}$ (East, Louis \& Hoffenberg, I 972). Omission of amino acids from the incubation medium is associated with very low rates of synthesis; supplementation to physiological concentrations increases these rates twofold, but no further improvement is noted when these concentrations are exceeded.

It is desirable to examine and compare the results obtained by these various in vitro techniques, most of which have been applied to the rat liver. A normal rat liver in vivo synthesizes about $\mathrm{I}-\mathrm{I} 2 \mathrm{mg}$ albumin $/ \mathrm{h}$ per $300 \mathrm{~g}$ body-weight, a rate which has not consistently been demonstrated by any in vitro technique. Using the isolated perfused rat liver, $60-80 \%$ of the rates obtaining in vivo can be achieved, but no variety of supplementation or stimulation has succeeded in pushing synthesis rates above these values. John \& Miller ( I 969) added cortisol, amino acids, and insulin to their rat liver perfusions, but still failed to achieve a 'normal' in vivo rate. With incubated liver slices or isolated liver cells, synthesis rates for albumin are even lower, about 20 and $10 \%$ of the in vivo rates respectively.

It is important to keep these limitations in mind in the consideration of all in vitro work, as it may be argued that optimum function is not being achieved under the conditions of study. It seems reasonable, none the less, to use such systems for comparative studies, especially where control periods are available.

\section{Dietary protein, amino acids and plasma protein synthesis}

In kwashiorkor or experimental dietary protein deprivation in man or animals, the plasma albumin concentration falls and, indeed, this fall provides one of the most sensitive criteria for the diagnosis of protein malnutrition. Neither increased catabolism nor loss of albumin to extravascular sites can account for it, in fact, the rate of catabolism of albumin is actually decreased and transfer of albumin has been 
demonstrated in the opposite direction, that is from extra- to intra-vascular compartments. Indirect studies in man based on the metabolism of ${ }^{131} \mathrm{I}$-labelled albumin and direct studies in the rat using the $\left[{ }^{14} \mathrm{C}\right]$ carbonate method have shown quite clearly that the fall in plasma albumin concentration and mass after dietary protein deprivation results from reduced albumin synthesis. The timing of this response to protein deprivation is not yet certain. In rats, K. N. Jeejeebhoy (personal communication) found a fall in albumin synthesis rate to $30 \%$ of normal by the $3^{\text {rd }}$ day of exposure to a non-protein diet; by the I $^{\text {th }}$ day the rate was only $6 \%$ of normal. Our own findings (Kirsch, Frith, Black \& Hoffenberg, 1968) suggested a slower and less dramatic adaptation. A possible explanation for this discrepancy might be found in the even more pronounced effects of starvation-a fall of albumin synthesis rate from normal values of $34 \mathrm{mg} / \mathrm{I} / 00 \mathrm{~g}$ liver per $2.5 \mathrm{~h}$ to $18 \mathrm{mg}$ was reported when livers were taken from rabbits fasted overnight (Rothschild, Oratz \& Schreiber, 1972). If removal of protein from the diet is associated with loss of appetite and reduced food intake, more rapid and severe effects may be noted. The importance of separating the sequelae of protein deprivation from those of starvation in all studies of this sort cannot be overemphasized.

These in vivo findings have been reinforced by isolated organ studies. Livers removed from rats given a non-protein diet for $\mathrm{I}_{4-3} \mathrm{I}$ I d synthesize less albumin than normal when perfused with normal rat blood or with a heterologous rabbit plasmarat red blood cell mixture (Hoffenberg et al. 197x; Tavill et al. 1972). Similarly, cells isolated from livers of rats deprived of dietary protein produce far less albumin than those from normally-fed animals (see later). In neither instance does addition of amino acids to the medium increase the rate of albumin production. It is interesting that whole livers or isolated cells from protein-deprived rats show markedly depressed rates of urea synthesis, and the former fail to incorporate ${ }^{14} \mathrm{CO}_{2}$ into urea or arginine. Yet, the ability of such livers to form urea from arginine seems unimpaired and there is no reduction in the rate of incorporation of $\left[{ }^{14} \mathrm{C}\right]$ arginine or $\left[{ }^{14} \mathrm{C}\right]$ lysine into albumin. These findings suggest that protein deprivation results in a failure of enzyme activity in the Krebs-Henseleit urea cycle, with no ratelimiting reduction of arginase activity or of amino acid activation. Direct measurement of urea cycle and amino acid activating enzymes in the livers of rats fed on a low-protein diet support this contention (Schimke, 1962; Stephen \& Waterlow, 1968). It is interesting to note that flooding amino acids into the portal vein of the perfused rat liver causes marked increases of urea production in normal and proteindeprived livers without an increase in albumin production (Tavill et al. 1972).

Reduction of the amount of protein produced by an organ could arise (a) because fewer cells participate in this production or (b) because each cell produces protein at a reduced rate. It is interesting to examine the performance of livers taken from protein-deprived rats. After $\mathrm{I}_{4-2 \mathrm{I}} \mathrm{d}$ of non-protein diet these organs weigh less than normal and their isolated cells are about two-thirds the size of control cells from normal livers, as judged by standard packed cell volume determinations. Albumin (and urea) production is low even when expressed in terms of liver weight or per liver cell. Whereas cells isolated from normal livers produce albumin at a rate of 


\section{Vol. 3 I Amino acid supply and polynucleotide and protein metabolism 269}

about $0.8 \mu \mathrm{g} / \mathrm{h}$ per $10^{6} \mathrm{cells}$, those from protein-deprived animals average 0.16 $\mu \mathrm{g} / \mathrm{h}$ per $10^{6}$ cells-a reduction to about $20 \%$ of the normal rate. The question still arises whether this reflects a general uniform retardation of albumin production or a 'withdrawal' of individual cells from their normal responsibility for albumin synthesis. Using antibodies fluorescent to albumin, Chandrasakharam, Fleck \& Munro (1967) adduced that the latter might be true: liver cells from rats fed on a non-protein diet showed an absence of fluorescence, which could be demonstrated in normal cells and to a greater degree in cells taken from animals fed on a high-protein diet. The interpretation of these findings is not certain, but they appear to suggest selective or intermittent function of individual cells. Rothschild et al. (1972) claim that much of the hepatic assembly and transport line for albumin is not in constant use, and they calculate that it is normally operating at about onethird of its capacity. Dietary protein or amino acid supply could thus regulate albumin synthesis by modifying the number of cells committed to this function, but little is known about ways in which the total capacity might thus be restrained.

If the alternative explanation is true - that all cells share in these adaptive responses by increasing or decreasing their individual output of albumin - then the mechanism by which such control is exercised needs to be clarified, in particular whether this is through transcriptional or translational influences. Much of the evidence on this point is conflicting, perhaps because of the differing methods and systems used to study it - the effects of starvation have not always been distinguished from those of protein deprivation, the performance of subcellular systems has often been equated with that of the whole organ, and the behaviour of the isolated whole organ has often been assumed to reflect its behaviour in vivo, despite its removal from obvious important influences such as hormones or concomitant amino acid release from large body stores (for instance muscle which constitutes $50-80 \%$ of the body amino acid 'reservoir'). Thus, despite the disaggregation of polysomes that is demonstrable in cell-free systems in the absence of amino acids (Baliga, Pronczuk \& Munro, 1968) or in the liver removed from animals fasted for $18 \mathrm{~h}$ (Rothschild, Oratz, Mongelli \& Schreiber, 1968 ), we have found preservation of a predominantly aggregated polyribosome population in livers removed from protein-deprived rats, which is maintained even after $6 \mathrm{~h}$ of perfusion in isolation (Tavill et al. 1972). This, together with the failure of amino acid supplements to increase protein production by normal or protein-deprived livers in vitro, suggests that the predominant adaptation to prolonged protein deprivation occurs at a transcriptional level and is compatible with the reduction of cellular RNA reported by others (Munro, Naismith \& Wikramanayake, 1953). However, Rothschild et al. (1972) have indicated the different effects on liver cell RNA of starvation and protein deficiency. In the latter, there is an initial rapid loss of RNA due primarily to very rapid rRNA degradation; after $48 \mathrm{~h}$ this rate of degradation decreases to less than control values. In starvation, a persistent high fractional rate of RNA degradation is found. In both instances RNA synthesis is reduced.

In a discussion of the role of amino acids in the regulation of protein synthesis it is reasonable to ask whether the supply of any single amino acid (or group) is 
critical. The role of tryptophan has received special attention, since protein synthesis by the liver seems especially sensitive to its availability in the diet (Wunner, Bell \& Munro, I966; Munro, I968; Sidransky, Sarma, Bongiorno \& Verney, 1968). After an amino acid meal, rat liver polysomes have been shown to aggregate, but this fails to occur if tryptophan is excluded from the meal. If the liver is first depleted of protein, the supply of other amino acids can also be shown to be rate-limiting. It seems, therefore, that the role of tryptophan is not specific for the maintenance of efficient protein synthesis. The sensitivity of the liver to a deficiency of it is explained by the fact that this is ordinarily the least abundant free amino acid in the organ (Munro, I968; Sidransky et al. 1968) and the concentration of other amino acids is normally maintained above the critical level by extensive recycling within the liver cell. Perfusion of the isolated rat liver with a medium lacking tryptophan elicited only a minor decrease in albumin synthesis and did not impair the production of fibrinogen, $\alpha_{1}$-acid glycoprotein or haptoglobin (Miller \& Griffin, 1971). Though tryptophan appears to have no stimulatory action on albumin synthesis when the polysomes are aggregated, it produces prompt and marked responses when disaggregation is present, for example after fasting or alcohol administration (Rothschild et al. I972).

So far, I have dealt only with the effects of a deficiency of protein or amino acids. It is equally important to ask whether synthesis of protein by the liver can be stimulated to supranormal levels by variations in amino acid supply. Except for conditions of dehydration, hyperalbuminaemia is not found clinically. This does not rule out the possibility of abnormally high rates of synthesis, as the development of high plasma albumin concentrations could be prevented by increased catabolism or loss through the kidneys. Increased albumin production has been reported after high-protein feeding, and the absorption of amino acids after a high-protein meal leads to marked changes in the polysome population of fasted animals - more aggregation, fewer oligosomes and subunits - and increased protein synthesis (Fleck, Shepherd \& Munro, 1965; Staehelin, Verney \& Sidransky, 1967; Wilson \& Hoagland, 1967 ). Jefferson \& Korner (1969) found high rates of $\left[{ }^{14} \mathrm{C}\right]$ phenylalanine incorporation into protein on perfusing the isolated rat liver with media containing ten times physiological concentrations of amino acids. In our experience, supplementation above normal levels failed to achieve any increase of albumin synthesis. In rats subjected to dietary protein deprivation, reintroduction of protein is associated with a rapid response of albumin production to levels that exceed those found normally; no other clear-cut and consistent example of 'super-induction' of albumin synthesis has been established, apart from the tryptophan effect mentioned earlier.

Finally, this review has been concerned almost exclusively with albumin synthesis by the liver. There is still far too little knowledge of production of other 'export' proteins in conditions of malnutrition or deprivation. Plasma transferrin concentrations ate reduced but to a lesser extent than albumin; serological measurement of transferrin production by the isolated perfused liver confirms the lower rate of synthesis when the organ is obtained from protein deprived animals (Tavill et al. 1972). Caeruloplasmin concentrations are also reported to be reduced in the 


\section{Vol.3 I Amino acid supply and polynucleotide and protein metabolism $27 \mathrm{I}$}

plasma of malnourished subjects, whereas fibrinogen appears to be affected later and less severely. In contrast, immunoglobulin concentrations are often high and the synthetic capacity is not impaired in protein malnutrition. The same immunity appears to apply to the 'non-export' protein, ferritin, which is produced promptly in response to giving iron, even under conditions of limited amino acid supply. The extent of competition between proteins for available amino acids in such states is not known, and the effect on other proteins of diversion of amino acids into the synthetic pathway of a single liver-produced protein is relatively unexplored.

One must conclude by emphasizing some of the limitations of this review. In the protein-deprived whole animal, muscle wasting occurs with the release into the bloodstream of large quantities of amino acids which may be used by the liver for the synthesis of proteins as well as smaller molecules such as urea, purines, and creatine. A consideration of the adaptation of the liver, in isolation, ignores the important modifying influences of changes in other tissues, as well as associated hormonal responses which may have direct or indirect effects on amino acid utilization and the production of protein by the liver. For this reason many of the assumptions and conclusions reached in this review may erpresent an oversimplification.

I thank Dr A. S. Tavill for his helpful criticism of this manuscript and for many valuable discussions. I acknowledge separately the freedom with which I have drawn on various chapters in the four volumes entitled Mammalian Protein Metabolism Vols I and 2 [H. N. Munro and J. B. Allison, editors] and Vols 3 and 4 [H. N. Munro, editor]. New York: Academic Press, 1967-70, without proper acknowledgement in the text.

\section{REFERENCES}

Baliga, B. S., Pronczuk, A. W. \& Munro, H. N. (1968). \%. molec. Biol. 34, I99.

Berry, M. N. \& Friend, D. S. (1969). F. cell. Biol. 43, 506.

Campbell, R. M., Cuthbertson, D. P., Matthews, C. M. \& McFarlane, A. S. (1956). Int. J. appl. Radiat. Isotopes $\mathbf{1}, 66$.

Chandrasakharam, N., Fleck, A. \& Munro, H. N. (1967). F. Nutr. 92, 497.

East, A. G., Louis, L. N. \& Hoffenberg, R. (1972). Expl Cell Res. (In the Press.)

Fleck, A., Shepherd, J. \& Munro, H. N. (1965). Science, N.Y. 150, 628.

Freeman, T. (1970). In Plasma Protein Metabolism p. 63 [M. A. Rothschild and T. Waldmann, editors]. New York: Academic Press.

Hoffenberg, R., Gordon, A. II. \& Black, E. G. (1971). Biachem. J. 122, I29.

Jefferson, L. S. \& Korner, A. (1969). Biochem. F. I11, 703.

John, D. W. \& Miller, L. L. (1969). F. biol. Chem. 244, 6r34.

Kirsch, R., Frith, L., Black, E. G. \& Hoffenberg, R. (1968). Nature, Lond. 217, 578.

McFarlane, A. S. (1963). Biochem. f. 89, 277.

Miller, L. L. \& Griffin, E. E. (I971). Am. F. clin. Nutr. 24, 7г8.

Munro, H. N. (1968). Fedn Proc. Fedn Am. Sacs exp. Biol. 27, 1231.

Munro, H. N., Naismith, D. J. \& Wikramanayake, T. W. (I953). Biochem. F. 54, I98.

Reeve, E. B., Pearson, J. R. \& Martz, D. C. (1963). Science, N.Y. r39, 914.

Rothschild, M. A., Oratz, M., Mongelli, J. \& Schreiber, S. S. (1968). F. clin. Invest. 47, 2591.

Rothschild, M. A., Oratz, M. \& Schreiber, S. S. (1972). New Engl. F. Med. 286, 748.

Schimke, R. T. (1962). J. biol. Chem. 237, 1921 .

Sidransky, H., Sarma, D. S. R., Bongiorno, M. \& Verney, E. (1968). J. biol. Chem. 243, 1123.

Staehelin, 'T., Verney, E. \& Sidransky, H. (I967). Biochim. biophys. Acta $\mathbf{x}_{45}$, 105.

Stephen, J. M. L. \& Waterlow, J. C. (1968). Lancet i, r I8. 
Sterling, K. (195r). F. clin. Invest. 30, I228.

Tavill, A. S., East, A. G., Black, E. G., Nadkarni, D. \& Hoffenberg, R. (1972). In Protein Turnover (Ciba Foundation Symposium). Amsterdam: Associated Scientific Publishers. (In the Press.)

Wilson, S. H. \& Hoagland, M. B. (1967). Biochem. F. 103, 556.

Wunner, W. H., Bell, J. \& Munro, H. N. (I966). Biochem. $\%$. ı01, 417. 